\title{
'n Nuwe-Testamentiese perspektief op 1892
}

\author{
L. Floor \\ Dept. Ou en Nuwe Testament \\ Potchefstroomse Universiteit vir $\mathrm{CHO}$ \\ POTCHEFSTROOM
}

\begin{abstract}
In this article it is argued that the unification (1892) of the tw'o Dutch churches, both rooted in the Reformed tradition, was premature. Prior to the unification, the doctrine of the covenant of grace and the vew on infant baptism, laught and preached in one of the churches and later on laught in the united churches, were strongly influenced by the theology of Abraham Kuyper. These teachings dealing with the doctrine of the church could not be jusified as fully biblical and in line with the reaching of the New Testament.
\end{abstract}

\section{Inleiding}

Die kerkgeskiedenis van die vorige eeu in Nederland bereik sy hoogtepunt in die dramatiese gebeurtenis van die Vereniging van 1892. Twee kerkgroepe wat albei uit die Nederlands Hervormde Kerk afkomstig was, vind mekaar om gesamentlik De Gereformeerde Kerken in Nederland (GKN) te vorm. 'n Gereformeerde kerkhistorikus het hierdie gebeurtenis toe twee hoofstrome langs die Hervormde Kerk saamgevloei het, aangedui as "een der grootste kerkhistorische gebeurtenissen van de 19e eeıw" (Praamsına, 1950:286)

Langs die breë stroom van die verenigde kerke $(G K N)$ vloei daar tot vandag 'n systroom, 'n kerk wat nie kans gesien het om saam te gaan met die hoofstroom wat langs die Nederlands Hervormde Kerk ontstaan het en wat met groot krag in die 20ste een inbeweeg het nie. 'n Klein groepie beswaardes uit die Christelike Gereformeerde Kerk kon nie met die saamsmelting instem nie en het apart bly voortbestaan. Hulle was nie teen 'n vereniging as sodanig nie. Hulle skryf in hul Bezwaarschrift: "Broeders! sluit thans nog niet definitief de door zovelen gevreesde Vereeniging" (Jongeleen, 1949:143)

Die beswaardes wat uiteindelik nie met die Vereniging kon saangaan nie, het die oorspronklike naam van die ou afgeskeie kerk behou, hoewel die enkelvoud later in 'n meervoud verander is: De Christelijke Gereformeerde Kerken in Nederland (CGKN). 
Van Teylingen (1944:29) skrywe dat in die veertigerjare van hierdie eeu toe in die GKN 'n stryd oor verbond en doop ontbrand het, verskillende beswaardes "de vereeniging van 1892 als een vergissing gebrandmerkt hebben". Was die Vereniging in 1892 werklik 'n vergissing? Hieroor word tot op hede, honderd jaar na die Vereniging, verskillend geoordeel.

Wel moet erken word dat die besware van die Christelike Gereformeerde lidmate mettertyd steeds sterker geldingskrag ontvang. Die ontwikkelinge in die Gereformeerde Kerke in Nederland het in 'n groot mate bevestig dat hulle besware om nie op daardie tydstip die Vereniging aan te gaan nie wel terdeë geregverdig was.

Die geskiedenis is egter nie die hoogste norm nie. Daarom wil ons in hierdie artikel die besware van die Afgeskeidenes (Chr. Geref. Kerk) toets aan die Woord van God. Diegene wat teen die Vereniging van 1892 beswaar aangeteken het, het veral in verset gekom teen Kuyper se spekulatiewe denke soos dit in die Doleansie reeds in die leer van die kerk en die leer van die verbond tot uitdrukking gekom het.

\section{Kerk en verbond}

Wanneer ons die besware van die Christelike Gereformeerdes teen die Vereniging van 1892 lees en weeg, dan trek die resultaat saam in twee punte, naamlik die Dolerendes se siening van die kerk en hulle opvattings oor die verbond wat tot uitdrukking gekom het in hul beskouing oor wedergeboorte en doop.

In hul beswaarskrif is onder andere die volgende opgeteken:

b. In den strijd der laatste jaren bleken de beginselen van Afscheiding en Doleantie met elkaar in strijd, vooral in de beschouwing van de Hervormde Kerk. Indien dan niet éen der twee beginselen in de Vereenigde Kerken aan het andere zal opgeofferd worden, waarvan kan hunne samenvoeging dan anders oorzaak zijn dan van twist en eindelooze verwarring.

e. En eindelijk is het ons een overwegend bezwaar voor gereformeerd te erkennen, wat door voorgangers der dolerende Kerken in den laatsten tijd in het publiek is uitgesproken en geleerd omtrent wedergeboorte en den Heiligen Doop (Jongeleen, 1949:43).

Op die Generale Sinode van die Christelike Gereformeerde Kerk te Assen in 1888 is by die bespreking van 'n eventuele vereniging met die Dolerendes die opmerking gemaak dat daar veral gelet moet word op "het verschil van de beschouwing over de verhouding der kerk tot de verkiezing, dan doop en de belijdenis" (Drayer, 1984:136). 
Om te oordeel of hierdie besware wettige besware was en of die Christelike Gereformeerdes reg opgetree het toe hulle nie kans gesien het om met die Vereniging van 1892 saam te gaan nie, kan ons die verdere verloop van die kerkgeskiedenis in Nederland volg om te kyk of daar 'n historiese regverdiging vir hulle daad was. Dit is egter gevaarlik om uit die gevolge van historiese gebeure die wil van God te probeer aflei (Berkouwer, 1950:217); die feite self moet eerder aan die Heilige Skrif getoets word. Die besware wat geopper is deur die lidmate van die Chr. Geref. Kerk wat uit die Afskeiding ontstaan het, was ten diepste veroorsaak deur die leer van Abraham Kuyper. Hy was die groot teoloog en kerklike strateeg uit die vorige eeu wat soos 'n generaal sy troepe sowel tot die Doleansie in 1886 asook tot die Vereniging van 1892 gelei het. Wanneer die besware van die Afgeskeidenes geweeg word, kan dit nie anders nie of ons word gekonfronteer met die denkwyse van Abraham Kuyper wat as 'n geniale denker die gerefonneerde teologie aan die einde van die $19 \mathrm{e}$ eeu sterk oorheers het.

\section{Die siening van die kerk - Kuyper se kerkleer}

In sy vergelykende studie tussen die Afskending van 1834 en die Veréniging van 1892 het Drayer (1984) daarop gewy's dat dit in 1892 ten diepste gegaan het om "de essentie van het kerk-zijn" (Drayer, 1984:121). Wat in 1892 deur die beswaardes betwis is en deur die voorstanders van die Vereniging verdedig is, het betrekking op die wese van dic kerk. Die Dolerendes het in die verenigde kerk in 1892 ' $n$ kerkbegrip ingedra wat onverenigbaar was met die kerkbeskouing van die Afgeskeidenes. Samevattend kom die kerkbegrip van die Dolerendes neer op die volgende: die gelowiges is wesenlik dic kerk, hoe gedefonneerd daardie kerk ook al mag wees. Die instituut is slegs iets 'toevalligs' of 'uitwendigs' (Veenhof, 1969:42). Die dolerende gemeentes was dan ook nie streng begrensd en duidelik afgebaken teenoor die plaaslıke Hervonnde kerke nie (Veenhof, 1969:352), en die kerk as organisme is belangriker geag as die kerk as instituut. Hierdie opvatting stem ooreen met Kuyper se siening van die kerk. In sy Traciaat van die Reformatie der kerken onderskeı Kuyper drie vorme van kerkwees:

* Kerke met nog 'n taamlik suiwer bediening van Woord en sakrament.

* Kerke waar die goeie bediening van Woord en sakrament ontbreek, maar waar nog bidders is.

* Kerke wat as dood beskou moet word ondat bygeloof en afgodery die plek van die waarheid ingeneem het (Kuyper, 1884:31-32,177).

Kerk bestaan volgens Kuyper nog waar daar gelowiges, bidders bymekaar kom. Die essensie van die kerk is egter ook nog bespeurbaar waar daar die potensie, die moontlikheid dat daar gelowiges kan wees, aanwesig is (Kuyper, 1884:32, 
176). Kuyper gaan selfs so ver om te beweer dat die wese van die kerk op 'n bepaalde plek aanwesig is as daar nog krag tot reformasie is, as daar nog uitverkorenes is, ook al het hulle nog nie tot bekering gekom nie (Kuyper, 1884:31-32).

Kuyper se visie op die kerk hang ten nouste saam met sy leer van die wedergeboorte. Solank daar in 'n plaaslike kerk nog die potensie, die moontlikheid tot wedergeboorte is, so lank is die wese van die kerk nog aanwesig (Kuyper, 1884:32; Velema, 1952:11) - die instituut is iets bykomstigs.

Wanneer ons met hierdie problematiek na die Nuwe Testament gaan om 'n Bybelse perspektief op die probleem te kry, dan ontdek ons dat die Nuwe Testament baie breedvoerig oor die kerk spreek. Dit is onmoontlik om in die kort bestek van 'n artikel aan te toon wat die Nuwe Testament oor die kerk leer. Deur van beelde gebruik te maak, belig die Nuwe Testament egter verskillende wesenseienskappe en fasette van kerkwees. Aan die een kant word die kerk voorgestel as 'n liggaam, ' $n$ volk, 'n bruid, 'n kudde, terwyl dit aan die ander kant vergelyk word met 'n gebou, ' $n$ tempel, 'n pilaar, ja selfs met 'n brood (Floor, 1981: 60-61). Twee wesenskenmerke van die kerk staan egter uit, naamlik die organiese aard van die kerk en daarnaas die institutêre aard van die kerk. As die liggaam van Christus, as die volk van God, is die kerk 'n organisme (1 Kor. 12: 12, Ef. 5:30; Kol. 1:24). Die kerk as liggaam van Christus het ook 'n bepaalde struktuur ontvang. In sy beskrywing van die kerk as die liggaam van Christus wys die apostel op verskillende liggaamsdele wat bymekaar pas en saam 'n eenheid vorm; elkeen van hulle vervul sy funksie (Ef. 4:16). Die liggaamsdele is die ampte waarvan die apostel in Efesièrs 4:11 gepraat het. Die vroeè kerk was aanvanklik institusioneel georganiseer en in die Nuwe Testament is geen teenstelling tussen die organiese en die institusionele aard van die kerk nie. Uit die Nuwe Testament is dit duidelik dat die kerk 'n amptelike struktuur besit (vgl. Ridderbos, 1965:206); die institutère aard van die kerk is nie ondergeskik aan die organiese aard van die kerk nie; die kerk is die volk van God (1 Pet. 2:9). Die kerk is egter ook soos 'n gebou wat 'n struktuur besit (Ef. 2:21-22). Die organisme van die kerk is op 'n deur God gegewe wyse 'n instituut, en die instituut is 'n organisme. Die kerk in haar institutêre gestalte word gekenmerk deur die ampte wat Christus aan sy kerk gegee het (Rom. 12: I Kor 12; Ef 4:11).

Die Christelike Gereformeerde Kerk wat uit die Afskeiding gebore is, het hulle in hulle siening van die kerk sterk deur hierdie gegewens uit die Skrif laat lei. Ook was die Belydenis (NGB) vir hulle 'n rigsnoer. Hulle het die kerk beskryf as 'n vergadering van ware gelowiges, van hulle wat met hart en wil en deur die krag van die geloof in een en dieselfde Gees saamgevoeg en verenig is (art. 27 NGB). In navolging van Hendrik de Cock sien hulle die kerk as die kudde van Christus of die 'schaapskooi Christi', maar tegelyk het hulle baie sterk die amptelike 
struktuur van die kerk as iets wesenliks beskou en nie as iets bykomstigs nie (art. 30 NGB).

Bavinck, een van die woordvoerders van die Afgeskeidenes het met groot oortuiging beklemtoon dat Christus 'n geïnstitueerde kerk op aarde gevestig het deur aan sy kerk 'n gepaste institutêre gestalte te gee (Bavinck, 1930:331,354). Die instituut vloei voort uit die heerskappy van Christus wat Kurios, Heerskappyvoerder is (Van der Walt, 1976:49).

Kuyper en sy volgelinge het ook die kerk beskryf as organisme en as instituut. In sy beskrywing van die kerk as instituut het Kuyper aansluiting gesoek by die gereformeerde kerkbeskouwing soos dit in die gereformeerde belydenis tot uitdrukking gekom het, maar in sy pleidooi vir die kerk as organisme soek Kuyper ook aansluiting by die wêreld (Kuyper, 1903:13,29). Die kerk as organisme wys op die optrede van die gelowiges in die wêreld. Kuyper het aan die kerk as organisme meer gewig gegee as aan die kerk as instituut. Die instituut is nie onbelangrik nie; tog is dit iets bykomstigs met betrekking tot die wese van die kerk.

Agter hierdie benadering vind ons Kuyper se tweedeling van essentia en existentia wat, soos Velema in sy proefskrif oortuigend aangetoon het, beslissend is vir Kuyper se teologie as geheel (Velema, 1957:291-233).

Wanneer ons Kuyper en sy volgelinge se siening op die kerk vergelyk met dié van die beswaardes wat nie met die Vereniging saangegaan het nie, is daar 'n beduidende verskil. F.M. ten Hoor, een van die skerpsinnigste teoloë in die Christelike Gereformeerde Kerk, het in sy bekende geskrif Afskeiding en Doleanne die volgende oor die kerkbeskouing van die Doleansie geskrywe:

De opvatting van het wezen der kerk, waarvan de Doleantie uitgaat, is principieel fout, wijl zij de oorsaak van de wording der kerk voor haar wezen aanziet, door de kerkformeerende kracht het wezen der kerk te noemen, brengt men een stuk van het Ethisch-Pantheisstische stelsel over in het Gereformeerde systeem (Ten Hoor, 1890:55).

Toe Ten Hoor, onder andere van professore H. Bavinck en D.K. Wielenga, skerp kritiek ontvang het, skrywe hy in 'n volgende geskrif Afscheiding of Doleantie: "Wij plaatsen ons met de Afscheiding op het standpunt der Schrift en der Belijdenis en beschouwen de sichtbare kerk slechts uit één oogpunt. De kerk is de vergadering der gelovigen" (Ten Hoor, 1891:35). Diegene wat nie met die Vereniging saamgegaan het nie, beskrywe die kerk in terme van artikel 27-29 van die NGB; daarmee staan hulle in lulle kerkbegrip baie nader aan die Bybel as die volgelinge van Kuyper. 
Velema het daarop gewys dat agter die kerkbeskouing van Kuyper en sy volgelinge ' $n$ bepaalde visie op die skepping gesien moet word. Volgens Velema is Kuyper se kerkbeskouing gebou op sy skeppings- en herskeppingsleer. "Evenals de historische realiteit bijkomstig is, bij de essentie der dingen, evenzo de zichtbare kerk bij de onzichtbare" (Velema, 1957:197). Kuyper was oortuig "dat het wezen der kerk nog geenszins teloor is gegaan, ook al waren de laatste uitverkorenen onder de volwassenen gestorven en nog geen der uitverkorenen onder de jongeren tot bekering gekomen" (Kuyper, 1884:31). Die wese van die kerk lê volgens Kuyper "dus niet in de genademiddelen en noch in de instelling die deze genademiddelen helpen aanwenden" (Kuyper, 1884:30).

Daar sit in Kuyper se kerkleer, wat via die Vereniging deur die Dolerendes in die Gereformeerde Kerke in Nederland ingedra is, ' $n$ afbuiging van die Bybelse beskouing oor die kerk. Nie die Skrif nie, maar die geskiedenis en die sosiale werklikheid is die grond vir Kuyper se leer aangaande die kerk. Die werklikheid van die lewe self, en met name die werklikheid van die diversiteit wat aanwesig is in die subjektiewe toe-eiening van die waarheid, bring Kuyper daartoe om 'n visie op die sigbare bestaanswyse van die kerk te ontwikkel. Hierdie visie waarvoor hy hoegenaamd geen Skrifgronde het nie, pas in by 'n bepaalde dogmaties-wysgerige visie op die werklikheid as 'n organiese geheel wat evolusionêr ontwikkel, en in die proses die ganse rykdom ontplooi wat God aan die begin in die skepping gelê het (Jonker, 1989:19). Veenhof het tereg die stelling gemaak dat in die kerkleer van Kuyper, wat later deur sy volgelinge oorgeneem is, ' $n$ brok natuurlike teologie ingevoer is (Veenhof, 1969:124).

Die ontwikkelinge in die Gereformeerde Kerke in Nederland het die bewys gelewer dat so 'n kerkleer nie bestand is teen die geweldige druk van die sekularisasie nie. Hulle wat Kuyper se erfgename moes wees, neem stellinge aan wat Kuyper self altyd bestry het. Die volgelinge van Kuyper het volgehou dat die kerk van groot betekenis is vir die samelewing en hulle het op allerlei maniere ' $n$ direkte verband gelê tussen die kerklike instituut en die samelewing (Dekker, 1987:202).

Die leer van die 'gemene gratie' speel hierby natuurlik ook 'n baie belangrike rol.

Die vraag moet gevra word in hoeverre Kuyper aandadig is vir die ontwikkelinge wat in die GKN plaasgevind het en of Kuyper verantwoordelik gehou kan word vir wat na 1892 in die verenigde Gerefonmeerde Kerke in Nederland plaasgevind het? Velema het op hierdie vraag 'n duidelike antwoord gegee.

Kuyper heeft met zijn beperking en isolering van het instituut van de kerk een vrijheid geschapen, waarvan christenen die zich bewogen op het gebied van de gemene gratie, gebruik, ja, misbruik gemaakte hebben ... Het is de tragedie van Kuypers theologie dat hij de particulariteit van de genade 
gerelativeerd heeft door de verbinding met de breedte van de gemene gratie. Daarmee heeft hij de bijl aan de wortel van zijn eigen levenswerk gelegd. Het tragische is dat Kuypers eigen nazaten die bijl gebruikt hebben om de boom te doen vallen. Van binnenuit is Kuypers levenswerk ondermijnd. Dat is mogelijk geworden, doordat Kuyper in zijn eigen theologie aan zijn nazaten een aanknopingspunt heeft gegeven (Velema, 1989:70).

Ondanks Kuyper se indrukwekkende ontwerp van die kerk vind ons daarin tog 'n stuk idealistiese wysbegeerte wat so kenmerkend was vir die 19de eeu. As kind van die 19de eeu kon Kuyper hom nie ontworstel aan die Duitse Idealisme wat sy denke beheers het nie. Tereg teken Velema die teologie van Kuyper as "een Idealistische schering met een Gerefonneerde inslag" (Velema, 1989:61).

Die kerkbeskouing van die beswaardes wat ons later in De Christelijke Gereformeerde Kerken in Nederland as leer aangaande die kerk terugvind, is baie meer in ooreenstemming met die Heilige Skrif. Hierdie kerkbeskouing vertoon duideliker die beeld van die kerk wat die Nuwe Testament vir ons teken. Die feit dat die Chr. Geref. lidmate nougeset aan die Belydenis vasgehou het, is die voor die handliggende verklaring hiervoor

\section{Die leer van die verbond}

'n Tweede punt van kritiek wat die beswaardes verhinder om met die Vereniging van 1892 saam te gaan, is die beskouing oor wedergeboorte en doop wat deur die Dolerendes in die Verenigde kerk ingebring kon word. Die beswaardes noem dit selfs in hulle beswaarskrif "een oorwegend bezwaar". Die beswaardes kon nie dic leer oor die wedergeboorte en die doop, wat die Dolerende kerke openlik geleer het, as gereformeerd erken nie. Volgens hierdie opvatting word die doop nie in die eerste plek gesien as 'n verseëling van God se beloftes nie, maar as 'n verseëling van genade wat veronderstel word om aanwesig te wees (Veenhof, 1949:176-197). Daar moet erken word dat die leer van die veronderstelde wedergeboorte nie in 1892 deel gevorn het van die offisiële leer van die Gereformeerde Kerke nie. By die Vereniging van 1892 wat albei kerke geraak het, was daar tweërlei voorstellings ten opsigte van wedergeboorte en doop. Die vraag kan dus gestel word of dit voldoende redes vir die beswaardes was om nie met die Vereniging saam te gaan nie. Hieroor word verskillend geoordeel.

Die Christelike Gereformeerde Kerk wat nie met die Vereniging van 1892 kon saamgaan nie, erken dat die leer van die veronderstelde wedergeboorte in 1892 nie die leer van die Nederduits Gerefonneerde Kerke was nie en dit het in daardie jaar ook nie die amptelike leer van die Gereformeerde Kerke in Nederland geword nie. Hulle beswaar was egter daarteen dat die leer wel geduld is 
Die verdraagsaamheid teenoor die leer van die veronderstelde wedergeboorte loop ruim 50 jaar later daarop uit dat dié leer konfessioneel bekragtig is in die bekende Sinodebesluite van 1943/44 (Acta, 1943-1945:370).

Die beswaar ten tyde van die Vereniging was dat daar met 'n wedergeboortebegrip gewerk is wat nie Bybels is en in die belydenis te vinde is nie. Op grond hiervan mag volgens die beswaardes so 'n leer in die kerk selfs nie geduld word nie. Die siening van verbond en doop waarteen die beswaardes geappelleer het, hang saam met ' $n$ bepaalde verbondsbeskouing.

Die verbondsleer wat in die Verenigde Gereformeerde Kerke steeds meer ingang gevind het, sluit aan by Kuyper se siening van die verbond. Dit is opmerklik dat daar later selfs by die kuratore van die Vrije Universiteit die vrees was of daar by Kuyper wel plek was vir 'n waarlik gereformeerde verbondsleer (Veenhof, s.j. $: 240)$.

Ook in sy verbondsleer vind ons Kuyper se analogie-gedagte terug. Hy konstrueer ' $n$ idea foederis wat kragtens die analogie deur die skepping na die beeld van God op God oorgebring word. Soos in alle ander onderdele van sy teologie gryp Kuyper ook in sy verbondsleer terug na die wese van God. God het die dinge van die wêreld geskape gedagtig aan die waarheid van sy eie wese. Die verbondslewe van die mens is derhalwe geskape na die heilige model van die verbond van God.

Velema het op 'n duidelike wyse aangetoon hoe Kuyper in sy verbondsleer probeer het om hom te ontworstel aan die Duitse Idealisme maar dat hy nie daarin kon slaag nie (Velema, 1957:184). Volgens Kuyper is die verbond nie opgerig met die gelowiges en hul saad nie, maar met die uitverkorenes. Kuyper het die verbond na die ewigheid getransponeer en prakties met die verkiesing gelykgestel. Die gedagte van die organisme van die genadeverbond onder Christus is beheersend vir Kuyper se verbondsidee. Hy omskryf die verbond as ' $n$ verbond wat gesluit is met Christus wat die Hoof is van sy organiese liggaam. Kuyper maak in sy verbondsleer ' $n$ onderskeid tussen wesenlike bondgenote en skynbondgenote. Die heilskat van die verbond is uiteindelik alleen bestem vir die uitverkorenes. Ten tyde van die Vereniging het beswaardes uit die Christelike Gereformeerde Kerk reeds aangevoel dat hierdie verbondsleer te spekulatief en nie in ooreenstemming met die Skrif en die Konfessie is nie. Hulle was bang dat hierdie verbondsleer in die verenigde kerke verder sou deurwerk en daarom die oproep in hulle beswaarskrif: "Broeders! sluit thans nog niet definitief de door zoovelen gevreesde Vereeniging" (Jongeleen, 1949:143).

Die verbondsleer wat in die Christelike Gereformeerde Kerk voor 1892 praktiese gemeengoed was, is op ' $n$ oorsigtelike manier saamgevat in die dogmatiek van Van Genderen en Velema (1992:493-521). Hierdie verbondsleer is baie minder 
spekulatief en sluit nou aan by die Heilige Skrif wat stel dat die genadeverbond opgerig is met die gelowiges en hulle kinders. Dit is ook die perspektief wat die Nuwe Testament ons bied op die verbond. Wanneer ons die verbondsleer, wat in die Verenigde Gereformeerde Kerke al hoe meer ingang gevind het, vergelyk met wat die Nuwe Testament ons oor die verbond leer, is daar beduidende verskille. In navolging van die Ou Testament is ook die kern van die verbondsleer van die Nuwe Testament die heerlike versekering dat God vir die gelowiges en hulle kinders God is (Matt. 28:19). Die belofte van die verbond is nie slegs aan die verkorenes geadresseer nie maar aan die gelowiges en hul kinders (Hand. 2:39). Daar is geen grond om in navolging van Kingdon (1975:88) 'kinders' hier as 'geestelik' te interpreteer nie.

In die Nuwe Testament is daar drie aspekte van die verbond wat besondere aandag kry:

* die kollektiewe aard van die verbond,

* die persoonlike gemeenskapskarakter van die verbond,

* die regskarakter van die verbond.

Daar moet daarop gelet word dat in die Nuwe Testament sprake is van die kollektiewe aard van die verbond die verbond is nie op ' $n$ individualistiese manier tussen onafhanklike individue en God gesluit nie. Petrus praat in Handelinge 2:39 van kinders in die meervoud. Die huis of die huisgesin is opgeneem in die verbond (Hand. 10:44; 16:15; 16:33; 18:8, 1 Kor. 1:16). Soos in die Ou Testament kinders en selfs slawe met hul gesime in die verbond opgeneem is (Gen. 17:12-13), so is die verbond in die Nuwe Testament kollektief van aard.

Die kollektiewe aard van die verbond sluit egter die persoonlike geloof nie uit nie. Dit is belangrik om by die kollektiewe aard van die verbond steeds te onderskei tussen die regskarakter en die gemeenskapskarakter van die verbond. Die Nuwe Testament lê sterk klem op persoonlike geloofstoe-eiening kragtens die wedergeboorte. Die regsposisie wat die kind in die verbond beklee, word 'n intieme gemeenskapsverhouding wanneer hy sodanig tot sy verstand gekom het dat hy self Jesus Cliristus, die Middelaar van die verbond, in die geloof omhels as sy Verlosser en Here. Egter wedersydse gemeenskap met God kom eers tot stand wamneer die verbondskind in persoonlike geloof antwoord op die genade wat in die verbond gegee word. Dan word die verhouding verdiep tot wedersydse gemeenskap, sonder dat die gemeenskapskarakter die juridiese stipulasies ophef (Strauss, 1982:283). Daarom is dit belangrik om in die verbondsleer van die Nuwe Testament goed te onderskei tussen die regskarakter en die gemeenskapskarakter van die verbond. 
Die regskarakter van die verbond kom in die Nuwe Testament ook sterk na vore - die brief aan die Hebreërs is hiervan 'n duidelike voorbeeld. Die beloftes van God in die Nuwe verbond is tegelyk ook 'n roeping tot geloofsgehoorsaamheid en geloofsoorgawe (Heb. 4:1;6:12;10:23,36; 12:25). Die verbondstoesegginge hou nie net in dat die Here op 'n soewereine manier regte en verpligtinge teenoor sy bondgenoot op homself neem nie, maar dat Hy ook verpligtinge op sy bondgenote lê.

Hierdie verpligtinge impliseer dat daar ook sanksies en strafafdreiging aan die nuwe verbond verbind is. Wanneer die skrywer van die Hebreërbrief in hoofstuk 10:25-31 die dreiging van verbondswraak verkondig, staan dit in die nouste samehang met die geweldige heilsindikatiewe van 10:19-25. Aangesien die nuwe verbond groter regskrag het as die ou verbond (Heb. 8,6,10) is die wraak van die nuwe verbond des te intenser en vreesliker (Heb. 12,21-25). Verbondswraak is steeds en in 'n verskerpte mate 'n struktuurelement van die nuwe verbond (Buys, 1984:104).

Wanneer ons vanuit die Nuwe-Testamentiese perspektief na $1892 \mathrm{kyk}$, dan moet ons met die beswaardes saamstem dat wat in die Dolerende kerk oor die verbond geleer word beswaarlik as gerefonneerd ja, as Bybels erken kan word.

Die vrees van die beswaardes was nie heeltemal ongegrond nie. In die 20 ste eeu werk die verbondbeskouing van Kuyper steeds verder deur in die Gereformeerde Kerke. 'n Kerkleier soos Aalders verklaar onomwonde dat die Sinaitiese verbond met die hele volk opgerig is, terwyl die nuwe verbond slegs met wedergeborenes opgerig is (Aalders, 1939:159).

Eintlik is daar in die verbondsopvattinge van Kuyper en sy volgelinge geen plek meer vir verbondswraak nie.

Wanneer ons die verbond vanuit die verkiesing benader, dan word dit baie moeilik om rekenskap te gee van baie gegewens uit die Nuwe Testament waar sprake is van verbondsbreuk en verbondswraak. Tekste soos Joliannes 15:1-6; 1 Korintiërs 10:1-13, Hebreërs $6: 4-6 ; 10: 29-31 ; 12: 25-29$ en 2 Petrus $2: 1$ is dan moeilik verklaarbaar (Van Teylingen, 1944:24).

Met die verbondsbeskouing van die Doleansie kry ons ook 'n ander siening op die wedergeboorte en die doop.

\section{Die leer van die wedergeboorte}

Die beswaardes het in die Dolerende kerk beskouinge oor die wedergeboorte gehoor wat volgens hulle in stryd was met Skrif en Konfessie. Meer en meer is die opvatting verdedig dat die wedergeboorte onmiddellik plaasvind en dat die 
Woord as die saad van die wedergeboorte daarby nie 'n rol speel nie; die wedergeboorte vind onmiddellik plaas deur die Heilige Gees.

In die geskrifte van Kuyper vind ons 'n merkwaardige eksegetiese uiteensetting van Jakobus 1:18 en 1 Petrus 1:13 (Kuyper, 1892:421; 1895:409). Dit is opvallend dat Kuyper van hierdie tekste verklarings gee wat mekaar uitsluit soos Velema (1957:149) aangetoon het. Wel neig Kuyper in sy pneumatologie steeds meer in die rigting om die Woord van God uit die goddelike daad van die wedergeboorte te verwyder. Dat die vrees van die beswaardes vir ' $n$ onbybelse leer oor die wedergeboorte nie heeltemal ongegrond was nie, blyk uit die geskiedenis. Grosheide, 'n vooraanstaande eksegeet in die Gereformeerde Kerke, gee 'n eksegese van Jakobus 1:18 waarin die Woord as die instrument van die Gees by die werk van wedergeboorte afgewys word (Grosheide, 1927:442; vgl. Floor, 1992: 68).

\section{Die leer van die doop}

As aanvaar word dat die verbond deur die uitverkiesing bepaal word, dan is die implikasie dat alleen die uitverkorenes gedoop moet word. Die konsekwensie sou die volwasse doop wees, maar daarvan wou Kuyper en sy volgelinge niks weet nie. Kuyper fundeer 'n ruimer doopspraktyk nie op die organiese behoort tot die gemeente aan wie Christus die doop as seël gegee het nie, maar op die onvermoë om suiwer te kan onderskei tussen eg en oneg (Kuyper, 1886:24, 142; vgl. Velema, 1957:186).

Volgens Kuyper kan eintlik alleenlik gedoop word as die inwendige genade, die wedergeboorte, by die dopeling plaasgevind het. Aangesien die verborge werking van die Gees by die kind nie waargeneem kan word nie, mag die wedergeboorte, ja selfs die verkiesing van die kind, veronderstel word omdat God organies in die lyn van die geslagte verkies (Velema, 1957:214).

Rondom 1892 het die debat tussen die Dolerendes en die lidmate van die Christelike Gereforneerde Kerk wat uit die Afskeiding van 1834 ontstaan het, gegaan oor die vraag wat die doop presies verseël. Is die doop die seël op ons geloof of verseël die doop die heilsbelofte vall God? Omdat geloof en doop so nou op mekaar betrek is, is dikwels die opvatting verkondig dat die doop die seël op die geloof druk.

Aangesien verskillende voorgangers in die kerke van die Doleansie sterk vanuit die uitverkiesing gedink het, het hulle verbondsbeskouing onder druk van die uitverkiesing gekom. Dit het weer gevolge gehad vir hulle doopbeskouwing. Volgens hul doopbeskouing moes alle wettig gedoopte kinders sowel as volwassenes vanweë hulle doop as ware gelowiges beskou word tensy die teendeel later in hul lewe blyk. Hierdie doopbeskouing is gehuldig om die eenvoudige 
rede dat die kerk die uitverkorenes nie kan onderskei nie. Daarom word volgens die oordeel van die liefde by die gedoopte kind die wedergeboorte en daarmee ook die geloof veronderstel.

Vir hierdie standpunt het voorgangers van die Dolerendes hulle beroep op die apostels wat in hulle briewe die gemeentes aanspreek as 'gelowiges, geroepe heiliges' waarmee hulle die geheel aanspreek en hul rig op die (veronderstelde) gelowige deel.

Die beswaardes was van oordeel dat op hierdie manier die geloof 'n wesenlike element van die doop gemaak word. Later is dit omskryf as geloof wat 'n konstitutiewe element van die doop geword het (Veenhof, 1949:367).

Die Nuwe-Testamentiese perspektief op die doop kan soos volg opgesom word. In die Nuwe Testament word die eenheid van geloof en doop inderdaad sterk beklemtoon. Die redding van die mens word verbind met sy geloof en sy doop, terwyl sy veroordeling met sy ongeloof gepaardgaan (Mark. 16:16). Die eenheid van geloof en doop lê egter in Markus 16:16 nie in onderlinge afhanklikheid nie, maar dit lê in die gesamentlike betrokkenheid van geloof en doop op die verkondiging van die evangelie (Mark. 16:15). In die verkondiging van die evangelie staan kruis en opstanding sentraal. Die doop is 'n bevestiging van wat in die evangelie aangebied word. Die doop mag nie op een lyn geplaas word met die geloof as middel om God se heil te ontvang nie. Saam met die geloof is die doop betrek op die verkondiging van die evangelie en op dit wat daarin aangebied word, naamlik die vergewing van sondes, maar geloof en doop is elk op 'n eie manier betrek. Wat in die doop sigbaar verkondig, beteken en verseël word, kan alleen deur geloof ontvang word.

Dit lyk soms of die Nuwe Testament doop en geloof op een lyn plaas. In Titus 3:5 noem Paulus die doop die middel waardeur God ons red en volgens Efesiërs 2:8 red Hy deur die geloof. In Galasiërs 2:20 word ons gekruisig wees saam met Christus verbind aan die geloof in die Seun van God, terwyl dieselfde heerlike heilswerklikheid in Kolosense 2:12 verbind word met die doop.

In sy kommentaar op Romeine 6:4 verduidelik Calvyn Paulus se merkwaardige uitspraak oor geloof en doop. Hy sê dat Paulus volgens sy gewoonte die wese en die vrug van die doop aan die uitwendige teken van die doop verbind, omdat hy hom in sy briewe tot gelowiges rig (Calvyn, 1950:181). Ook al sê die Nuwe Testament met nadruk dat ons deur die doop in die sterwens- en lewensgemeenskap met Christus opgeneem is, dan beteken dit nog nie dat die doop ons red nie Ons kan slegs gered word deur die heilsgebeure in Christus waarheen die doop verwys. Al word die doop die inlywing in Christus genoem, beteken dit hoegenaamd nie dat die Heilige Gees deur die doop die werk van wedergeboorte en inlywing bewerk nie. So 'n siening impliseer dat die werk van die Heilige Gees in 
die sakrament van die doop teenoor sy werk deur die Woord verselfstandig word Die doophandeling bring geen heil sonder geloof in Jesus Christus nie. Wanneer Paulus in Kolossense 2:12 stel dat ons saam met Christus begrawe is in die doop, dan wys hy direk daaná op die geloof deur te skrywe dat ons saam opgewek is deur die geloof.

In die Nuwe Testament word aan ons verkondig dat ons alleen deur geloof aan die heilsgebeure in Christus deel het. Wat met Christus gebeur het, het met ons gebeur kragtens ons inbegrepenheid met Hom - deur die geloof mag ons daarin deel. Wat aan ons in die Woord verkondig word, word in die doop uitgebeeld en verseël en gewaarborg; daarom rig die doop ons geloof op die heilsgebeure in Christus. Die geloof word nie deur die doop in ons harte gewerk nie. Die doop is gegee om die geloof in ons harte te versterk, om ons te verseker dat ons in Christus ingelyf is.

Die doop is beslis nie 'n waarborg dat ons glo nie. Ons lees in die Nuwe Testament van gedooptes wat blykbaar tog nie ware gelowiges was nie (Hand. 8:924; 1 Tim. 1:19,20; 2 Tim. 4:10).

Waar die geloof en die wedergeboorte by die doop veronderstel word, dreig die ontsaglike gevaar dat 'n veronderstelde geloof die plek gaan inneem van 'n werklik funksionerende geloof. Die noodsaak van wedergeboorte en bekering, die oproep tot geloofsbeoefening kan sodoende verswak omdat uitgegaan word van 'n 'vanselfsprekenheidsgeloof' wat radikaal van die ware geloof verskil. Dit het die beswaardes in 1892 raakgesien.

\section{Konklusie}

Die klein groepie beswaardes wat uiteindelik nie met die Vereniging van 1892 kon saamgaan nie, het intuitief aangevoel dat hierdie leer omtrent die kerk en die verbond nie volgens die Bybel is nie. Daarom het hulle hulle steeds kragtig beroep op artikel 27-29 van die NGB, hoewel diepgaande teologiese vormung by die beswaardes ontbreek het. Teologies-wetenskaplik was daar niemand wat hom met Kuyper kon meet nie. Daarom is dit des te meer merkwaardig dat daar in die kritiek op die kerkleer van die Doleansie so 'n suiwer Skriftuurlike geluid gehoor is. Dit kan net op een manier verklaar word, naamlik dat diegene wat in 1892 nie met die Vereniging kon saangaan nie, hulle streng gebind geag het aan die Konfessie en die liturgiese fonmuliere. Wat nie daarmee in ooreenstemming was nie, het hulle afgewys en wat nie daaruit gelegitimeer kon word nie, het hulle met wantroue bejeën (Van Teylingen, 1944:28).

Tereg kan die vraag gevra word of die beswaardes in 1892 voldoende redes gehad het om nie met die Vereniging saam te gaan nie. Daar is baie dinge wat in die Verenigde kerke na 1892 gewaardeer moet word: die stryd teen die moder- 
nisme, die handhawing van die volle gesag van die Bybel, die indrukwekkende aktiwiteite op die terreine van onderwys, sosiale wetgewing, Christelike politiek, die opbloei van die Bybeleksegese in twee reekse van kommentare, is dinge wat nie oor die hoof gesien mag word nie. Die beswaardes sou met hulle saamgaan in die verenigde kerk ongetwyfeld die geledere van hulle wat uit die Christelike Afgeskeide Kerk afkomstig was, versterk het.

Aan die ander kant is daar tog iets van 'n historiese regverdiging in die daad van die beswaardes. Die geskiedenis het bewys dat hulle vrees nie ongegrond was nie. By alles wat in die GKN lofwaardig was, het daar steeds meer plek gekom vir wat Kamphuis genoem het 'n "vanzelfsprekenheidsgeloof". Waar die wedergeboorte veronderstel word, moet daar vanselfsprekend ook geloof wees. Die gevolg is dat die verbond sy grense meer en meer gaan verloor en prakties universeel geldig gemaak word (Drayer, 1984:148). Wanneer die belofte alleen aan die uitverkorenes geadresseer is en die doop beskou word as die seel op inwendige genade, dan kom die geloof in die gedrang, want God se belofte word op hierdie manier onttrek aan die appèl van die geloof. Die doop word die seël van die reeds vervulde belofte; dit suggereer dat die gemeente op die punt van die ewige heil die stadium van die geloof en van die geloofsomgang met God verby is. Hierdie siening bring ons by 'n vanselfsprekenheidsgeloof wat die ware geloofslewe laat kwyn, uiteindelik laat verdwyn en lei tot die ondergang van die kerk (Kamphuis, 1985:312).

\section{Bibliografie}

ACTA van de Synode der Gereformeerden Kerken in Nederland 1943-1945. Kampen Kok AALDERS, C Ch 1939 Het verbond Gods Kampen Kok

BAVINCK, H 1930 Gereformeerde Dogmatiek IV Kampen Kok BERKOUWER, C.G 1950. De voorzienigheid God. Kampen Kok

BUYS, Ph J 1984 Die aard van die verbond en die implikasies daarvan vir evangelisasie Potchefstroom : PU vir CHO (Verhandeling - Th M )

CALVYN, J. 1950 Uitlegging van de zendbrief van Paulus aan de Romeinen Vert De Groot Amsterdam Van Bottenburg

DRAYER, M. 1984 De "Afscheiding" en 1982 (In Drayer, M \& Van 't Spijker W, red. In trouw gescheiden. Kampen Kok p 121-148.)

DEKKER, G 1987. Is Kuypers gedachtengoed nog bruikbaar? Delf : Miedema.

FLOOR, L 1981. Die evangelie van die koninkryk Pretoria : NG Kerkboekhandel

FLOOR, L 1992. Jakobus Brief van een broeder Kampen Kok

GROSHEIDE, FW 1927. De Brief aan de Hebreen en de Brief aan Jakobus Amsterdam Bottenburg

JONKER, W D 1989. Die pluriformiteitsleer van Abraham Kuyper In die Skriflig, 23(91): 12-33

JONGELEEN, J 1949 Hoofdzaken uit de geschiedenis der Gereformeerde Kerken in Nederland van 1795 tot heden Huizen: Bout

KAMPHUIS, J. 1985 Belofte of 'inwendige genade' (In Velink, K red. De Reformatie, 60 (15) $310-312$ ) 
KINGDON, D 1975. Children of Abraham. A Reformed Baptist View of Baptism, the Covenant and Children Sussex : Carey.

KUYPER, A. 1884. Tractaat van de Reformatie der kerken aan de zonen der Reformatie hier te lande op Luthers vierde eeuwfeest Amsterdam : Hovekes

KUYPER, A. 1886 Uit het Woord. Practijk der Godzaligheid. Amsterdam : Wormser

KUYPER, A 1892 Encyclopaedie der Heiligen Godgeleerdheid. Deel 2. Amsterdam Hovekes.

KUYPER, A 1895 Encyclopaedie der Heiligen Godgeleerdheid Deel 3 Amsterdam Hovekes

KUYPER, A. 1903 De Gemeene Gratie Leiden : Donner.

PRAAMSMA, L. 1950. Het dwaze Gods. Wageningen : Veenman

RIDDERBOS, H.N. 1965. Kerkelijke orde en kerkelijk recht in de brieven van Paulus (In Schippers R. red., Ex auditu verbi. Theologische opstellen aangeboden aan Prof. Dr. G C. Berkouwer p. 194-215)

STRAUSS, S A 1982 Alles of niks K Schilder oor die verbond Pretoria : Universiteit van Pretoria

TEN HOOR, FM 1890. Afscheiding en Doleantie Leiden : Donner

TEN HOOR, F.M 1891. Afscheiding of Doleantie Leiden: Donner

VAN DER WALT, JJ 1976 Christus as Hoof van die Kerk en die presbiteriale kerkregering Potchefstroom Pro Rege

VAN GENDEREN, J \& Velema, WH 1992. Beknopte Gereformeerde Dogmatiek Kampen : Kok

VAN TEYLINGEN, E G 1944 Aard en achtergrond van het geschil in de Gereformeerde kerken. Amsterdam : Buyten en Schipperheyn

VEENHOF. S.J. Predik het Woord Goes : Oosterbaan \& Le Cointre

VEENHOF, C 1969. Volk van God Enkele aspecten van Bavincks kerkbeschouwing Amsterdam Buyten en Schipperheyn

VEENHOF, C. 1949. Om de "unica Catholica". Goes: Oosterbaan \& Le Cointre

VELEMA, J.H 1952 Toen en thans (1892-1952) Haarlem Breemouwer

VELEMA, W. H. 1957. De leer van de Heilige Geest bij Abraham Kuyper 's-Gravenhage : Van Keulen

VELEMA, W.H 1989. Kuyper als theoloog - Een persoonlijke evaluatie na dertig jaar In die Skriflig, 23(91):56-73 
